\title{
Industrial synergy mechanism and operation mode research based on the retail industry
}

\author{
Min Haiqiang ${ }^{1, a}$, Chen $\mathrm{Xu}^{2, \mathrm{~b}}$ \\ ${ }^{1,2}$ School of Management and Economics, University of Electronics Science and Technology of \\ China, Chengdu 610054, China \\ anothing1691@126.com, ${ }^{\mathrm{b} x c h e n x c h e n @ 263 . n e t ~}$
}

Keywords: Industrial synergy; retail; real estate; financial capital

\begin{abstract}
In recent years, the rapid growth of commerce has led the upgrade of retail, real estate development mode. In the process, the trend of synergy development among retail, real estate and finance has been more and more obvious. In this paper, we analyzed the causes of the synergy development from three aspects, retail, real estate and finance industry. And through the compare of operation mode, we derived that multi-agent collaborative mode was more suitable for China's retail industry.
\end{abstract}

\section{Introduction}

Since the entry of WTO, China's retail enterprises have experienced more than ten years of market competition, China's whole economic has been transformed, and Chinese retailers also need to adjust the mode and upgrade the strategy for Chinese consumers and Chinese economy. However, the compound characteristic of retail commercial real estate investment requires the effective cooperation among retail, real estate and finance industry. Therefore, we researched the synergy mechanism among the three parts, and the results have important practical significance for the sustainable development of retail industry.

As the foremost research of industrial synergy, Igor Ansoff $(1965)^{[1]}$ completed the transformation of study field of social sciences. Afterwards, Chatterjee(1986) ${ }^{[2]}$, Campbell(2000) $)^{[3]}$, Hindle $(2004)^{[4]}$, $\mathrm{Li}(2007)^{[5]}$ respectively researched on the industrial synergy from the classification of the merger synergy, evaluation system, ways of collaboration, industry chain. With the social division of labor getting smaller, the research on the industry synergistic effect between different industries is getting more and more deeply. $\mathrm{Wu}(2004)^{[6]}$ named the operation synergy of retail and real estate as "real estate speculators + the commercial giant", and considered motivation as the following two point: market demand for commercial real estate; traditional real estate development model gradually losing competitiveness. $\mathrm{Hu}(2007)^{[7]}$ summed up the five typical mode of retail commercial real estate. Guo ${ }^{[8]}$ empirically studied the mechanism of the distribution of benefits of the synergy effect of the retail and real estate. Taking the real estate cycle fluctuations and industry as the main line, $\mathrm{Ba}^{[9]}$ analyzed and summarized the occurring mechanism and logic of Japan's real estate market bubble from the view of the financial policy researcher. However, those research on the industrial synergy of retail, real estate, finance mainly focused between any two subjects. Therefore, our research can card the synergy relationship of retail, real estate and finance for the future research.

\section{Industrial synergy mechanism based on the retail industry}

Retail and real estate belong to two different industries with disparate features. The former has adequate cash flow, while the profit is low. The latter has higher margins, but needs strong financial support and long payback period. Therefore, if the retail combine with real estate with lever effect of finance capital, it's no doubt that this will develop industrial synergy effect. Therefore we can follow that industrial synergy is an important means to achieve and enhance the value of retail, real estate and finance. Our paper analyzed the motivation of formation mechanism of industrial synergy from three different angles: retail, real estate and financial capital, shown in Figure 1. 


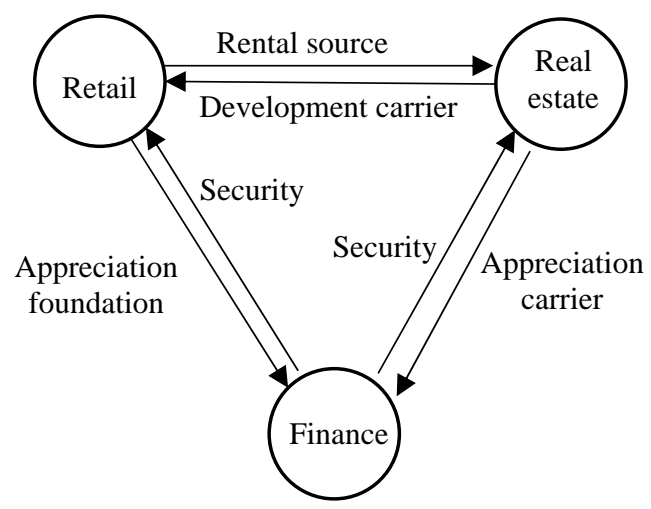

Figure 1 Collaborative network of the retail, real estate, finance

\section{Motivation of the retail partaking in industrial synergy.}

As the rental source of real estate, the retail development status determines the level of rental, as well as the financial capital improve potential. Therefore, the retail is not only the core and starting, but also the foothold of industrial synergy. The motivation of the retail partaking in industrial synergy has the following three point.

Firstly, it can increase the rate of expansion and enhance core competitiveness by making full use of the advantage of the land agent in site selection and combining with the appropriate form of commercial real estate portfolio.

Secondly, it can reduce the operating costs and improve the profitability through taking the methods of "retail + real estate" to enjoy the land agent's preferential policy.

Thirdly, for the retail enterprises who purchase the land and build the commercial real estate themselves, it can get financial rewards from the land appreciation.

Motivation of real estate participating in industrial synergy.

Because the retail attached to real estate and financial products are derived from the real estate projects, the real estate is the important carrier of retail development and capital appreciation. The cause of real estate enterprises participating in industrial synergy also have three point.

Firstly, for the residential market faces depth control and institutional reform, real estate enterprise want to evade the macroeconomic regulation and control by invest into commercial real estate.

Secondly, as many commercial real estate developers transition from residential real estate, they need to remedy the lack of retail experience by means of industry collaboration.

Thirdly, many developers need to recycle the funds as soon as possible to invest new projects through the financial capital market to invest into new project.

\section{Motivation of the financial capital participating in industrial synergy.}

Financial capital is security of healthy development for retail and real estate. The motivation of finance participating in industrial synergy is stable income and appreciation potential. With a large number of commercial real estate maturing, huge flow of people and consumption continuously drive the appreciation of commercial real estate. Exactly, mature commercial real estate has a good attraction to financial capital. Commercial real estate developers can cash out by the packing listed of projects, while public investors can obtain stable rental yields dividends.

\section{Operation mode of industrial synergy based on the retail industry}

\section{Operation mode of industrial synergy based on the retail industry.}

According to the current situation, retail, main industrial synergy mode of retail, real estate and financial is: Retail + Real Estate + list of packing mode. It can be specifically divided into multi-agent synergy mode and whole industry chain mode.

(1) Multi-agent synergy mode

Multi-agent synergy mode means retail, real estate and financial capital that belong to independent agents form collaborative network. In this mode, retail and real estate firstly combine to form the 
commercial real estate, then private equity (PE) buy and develop the commercial real estate project. When it is mature, it will be injected the real estate investment trust funds (REITs), and REITs provide exit channels for PE. Finally, it will be listed on packaging by REITs. The typical example is CapitaLand.

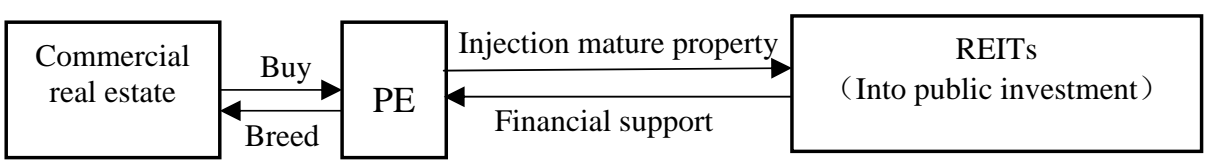

Figure 2 Multi-agent synergy mode

(2) Whole industry chain mode

Whole industry chain mode is that retail, real estate and financial capital belonging to one parent company form synergetic network. In this mode, land agent builds shops, and rent the shops to retail enterprise. The retail enterprise pay rental to the land agent. Then the commercial real estate projects are packaged into financial products to be listed. Financial products are controlled by parent company, and at last the dividend income from the financial products will go back to the parent company, then we can accomplish low-rent, or even zero rental operation as it shown in Figure 3, with a typical example of the U.S Wal-Mart.

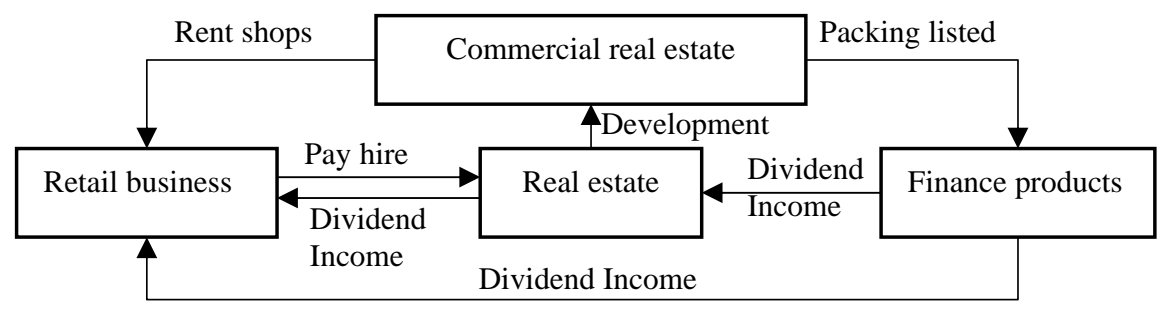

Figure 3 Whole industry chain mode

Comparison of synergy mode of operation based on the retail industry.

Two industrial collaboration modes have different characteristics from the following three perspectives: management structure, the payback period and risk.

(1) Whole industry chain mode mainly uses internal management, while multi-agent synergy mode often uses external management. However, internal management is built above the sufficient expertise and extensive management experience.

(2) As whole industry chain mode relates to all areas of entire chain, the industrial chain is significantly longer than the multi-agent collaborate mode, which means longer recovery cycle. In the multi-agent synergy mode, the operators of each stage are different. The time of the handover of the various stages is the time of cashing out.

(3) Enterprise that is whole industry chain mode undertake all aspects of risk, in which not only there's the capital risk, but also there's legal risk; while the opponents are only exposed to smaller risk of their stage.

We can find something from the comparison of the two modes. The multi-agent synergy mode has better adaptability in the lower level of enterprise development and the immature market mechanisms environment. The whole industry chain mode requires operators to have a strong management level and funds strength, and need healthy market environment and legal environment. From this point of view, multi-agent synergy mode is more suitable for the current Chinese retail enterprises.

\section{Conclusion}

Based on our research, we obtain the following conclusions: (1) the motivation of retailers to participate in synergy is to enhance competitiveness, reduce operating costs and enjoy land appreciation; the motivation of land agent is to evade macro-regulation, remedy retail experience, and cash out as soon as possible; financial capital mostly thought for income dividend. (2) main synergy 
mode of retail, real estate and financial is "Business + Real Estate + package listed", including the multi-agent synergy mode and the whole industry chain mode. (3) By comparing the two modes, multi-agent synergy mode is more adequate for Chinese enterprises to adopt.

\section{References}

[1]H.I. Ansoff., J. F. Weston. Merger objectives and organization structure, J. The Quarterly Review of Economics and Business. (3)(1962)49-58.

[2]S. Chatterjee. Types of synergy and economic value: The impact of acquisitions on mergering and rival firms, J. Strategic Management Journal. (7)(1986)119-139.

[3]A. Campbell. T. Ren. translated. Strategic synergy, M. Beijing: Mechanical Industry Press. (2000) 97-103.

[4]T. Hindle. Management thinking, M Beijing: CITIC Publishing House. (2004).

[5]W. Li. Industry chain enterprise division and synergies analysis, J. Cooperation in Economy and Technology. (4)(2007)40-41.

[5]D.Y. Wu. "Real estate speculators + the commercial giant" a new model of the commercial real estate Preliminary, J. Henan Commercial College. (1)(2004)10-12.

[7]Y.Q. Hu. Retail enterprises the commercial real estate business strategy perspective, J. Vitality of Enterprises. (9)(2007).

[8]X. Guo. Coupling effect of interest of the real estate and retail enterprise strategic synergy based on shapley value, J. Management Review. (11)(2010)93-98.

[9]S.S. Ba. Financial perspective of the real estate big cycle, M. Fujian: Xiamen University Press. (2012). 